\title{
Thermodynamic Behavior of Carbon in Molten Slags
}

\author{
Joo Hyun PARK and Dong Joon MIN
}

Department of Metallurgical Engineering, Yonsei University, Seoul 120-749, KOREA

\begin{abstract}
The solubility of carbon in the $\mathrm{MO}-\mathrm{B}_{2} \mathrm{O}_{3}\left(\mathrm{MO}=\mathrm{CaO}, \mathrm{BaO}\right.$, and $\left.\mathrm{Na}_{2} \mathrm{O}\right)$ and $\mathrm{CaO}-\mathrm{RO}\left(\mathrm{RO}=\mathrm{SiO}_{2}\right.$ and $\left.\mathrm{Al}_{2} \mathrm{O}_{3}\right)$ slags at high temperatures was measured to understand the thermodynamic behavior of carbon in molten slags. The solubility of carbon as a function of the composition of slags shows a minimum value, indicating that carbon dissolves by different mechanisms in the acidic and basic slags, respectively. The infrared spectra measurements indicate that the $\mathrm{B}-\mathrm{C}$ bond is about 1150 and $1140 \mathrm{~cm}^{-1}$ in the acidic region of the $\mathrm{CaO}-\mathrm{B}_{2} \mathrm{O}_{3}$ and $\mathrm{Na}_{2} \mathrm{O}-\mathrm{B}_{2} \mathrm{O}_{3}$ slags; hence, the incorporation of carbon into the borate network is confirmed qualitatively. The dissolution of carbon and nitrogen into the slags shows a similar behavior in the $\mathrm{B}_{2} \mathrm{O}_{3}$-bearing slags, while the different behavior is shown in the $\mathrm{CaO}-\mathrm{SiO}_{2}$ and $\mathrm{CaO}-\mathrm{Al}_{2} \mathrm{O}_{3}$ slags, based on the relationship between carbide capacity and nitride capacity.
\end{abstract}

KEY WORDS: carbon solubility; dissolution mechanism; infrared spectra measurement; B-C bond; carbon incorporation; borate network; nitrogen solubility; carbide capacity; nitride capacity

\section{Introduction}

A new breakthrough in steel materials has been achieved for various applications. For example, super fine and high strength steels have been developed for improving both strength and ductility. ${ }^{1)}$ For these purposes, the severe control of impurities such as $\mathrm{C}$ and $\mathrm{N}$ under condition of an ultra low level has been required. Hence, the solubility of carbon in molten slags has been investigated by many other researchers. ${ }^{2-12)}$

In previous works, the solubility of carbon was strongly dependent on oxygen partial pressure and basicity $\left(a_{\mathrm{O}^{2-}}\right)$ of slags. The dependence of carbon solubility on oxygen partial pressure has been known explicitly, while the effect of basicity on carbon dissolution has not been cleared. For example, the solubility of carbon increased by the increase of $\mathrm{SiO}_{2}$ content in the $\mathrm{CaO}-\mathrm{SiO}_{2}-\mathrm{Al}_{2} \mathrm{O}_{3}$ slag, ${ }^{2,7)}$ while the solubility increased with increasing content of basic oxides in other basic slags. Therefore, it was not clear whether carbon dissolution would be enhanced by the basic or acidic components. In the case of nitrgen ${ }^{8,12-14)}$ and silver ${ }^{15-17)}$ dissolution in molten slags, two types of dissolution mechanisms with the basicity of slags have been reported.

In the present study, the solubility of carbon in the $\mathrm{B}_{2} \mathrm{O}_{3}$ bearing slags, which had been known to have a wide rang of liquids, ${ }^{18)}$ and in the $\mathrm{CaO}-\mathrm{SiO}_{2}$ and $\mathrm{CaO}-\mathrm{Al}_{2} \mathrm{O}_{3}$ slags was measured to understand the reaction mechanism of carbon dissolution into the slags. In addition, the carbide capacity was suggested and compared to the nitride capacity.

\section{Experimental Procedure}

A super kanthal electric furnace was used for equilibration of molten slag and gas phases. The temperature was controlled within $\pm 2 \mathrm{~K}$ using an R-type (Pt-13Rh/Pt) thermocouple and a proportional-integraldifferential (PID) controller. The slag samples were prepared using reagent-grade $\mathrm{BaO}, \mathrm{Na}_{2} \mathrm{O}, \mathrm{B}_{2} \mathrm{O}_{3}, \mathrm{SiO}_{2}$, $\mathrm{Al}_{2} \mathrm{O}_{3}$, and $\mathrm{CaO}$ calcined from $\mathrm{CaCO}_{3}$. The schematic diagram of the experimental apparatus is shown in previous articles. ${ }^{11,16)}$

The slag samples of $10 \mathrm{~g}$ were held in graphite crucibles under $\mathrm{CO}$ atmosphere for equilibration. For the effect of oxygen partial pressure on the solubility of carbon, a mixture of $\mathrm{CO}$ and Ar was supplied by using mass flow controller (Matheson, Model 8284). The impurities of $\mathrm{CO}$ and $\mathrm{Ar}$ were removed by passing through $\mathrm{CaSO}_{4}$, $\mathrm{Na}_{2} \mathrm{O} \bullet \mathrm{CaO}$, silica gel, and, especially, $\mathrm{Mg}$ turnings at 753 $\mathrm{K}$ for Ar.

The equilibration time was predetermined to be 18 hours After equilibrating, the samples were quenched by Ar gas and crushed for chemical analysis. The content of carbon in slags was determined by a LECO (CS-300) analyzer. The uncertainty of the measured data could be estimated to be about $\pm 3.25 \%$.

The possibility of carbide formation could be evaluated using thermodynamic data available in the literature. ${ }^{19,20)}$ Because the evaluated activities of the carbides for the present experimental conditions are less than 0.05 , the discussion in the present study will be limited to the dissolved carbides in molten slags.

\section{Results and Discussion}

\subsection{Dissolution Mechanism of Carbon in Basic Slags}

Carbon has been known to dissolve into the basic slags by the following reaction: ${ }^{8,10-12)}$

$$
\begin{aligned}
& 2 \mathrm{C}(\mathrm{s})+\mathrm{O}^{2-}(\text { slag })=\mathrm{C}_{2}^{2-}(\text { slag })+1 / 2 \mathrm{O}_{2}(\mathrm{~g}) \ldots \\
& K_{(1)}=\frac{a_{\mathrm{C}_{2}^{2-}} \cdot p_{\mathrm{O}_{2}}^{1 / 2}}{a_{\mathrm{C}}^{2} \cdot a_{\mathrm{O}^{2-}}} \ldots \ldots \ldots \ldots \ldots \ldots \ldots \ldots \ldots \ldots \ldots \ldots \ldots \ldots \ldots \ldots \ldots
\end{aligned}
$$

where $K_{(1)}, a_{i}$, and $p_{\mathrm{O}_{2}}$ are the equilibrium constant of Eq. (1), the activity of $i$, and the oxygen partial pressure, respectively. Because graphite crucibles were used to fix the activity of carbon as unity, the following relation could be deduced: 


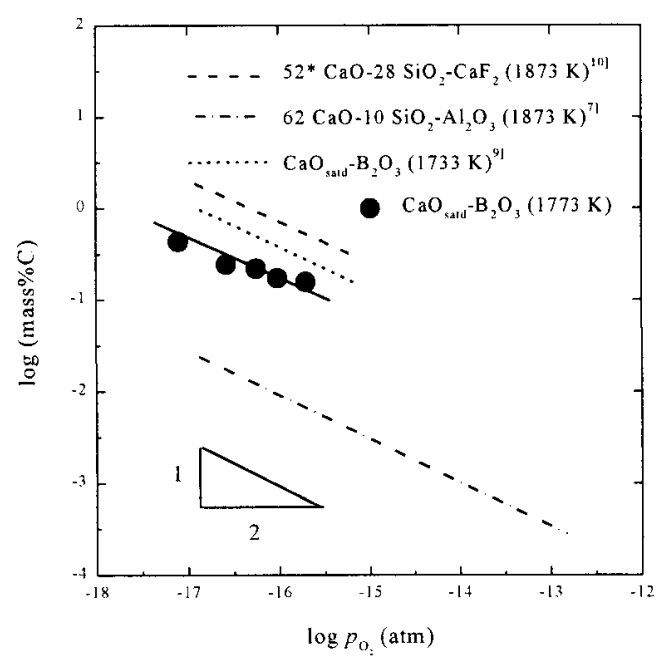

Fig. 1. Dependence of carbon solubility on oxygen partial pressure in various slags $(*$ : $\operatorname{mass} \%)$.

$$
\begin{aligned}
\log \left(\operatorname{mass} \% \mathrm{C}_{2}^{2-}\right)= & -1 / 2 \log p_{\mathrm{O}_{2}}+\log a_{\mathrm{O}^{2-}} \\
& -\log f_{\mathrm{C}_{2}^{2-}}+\log K_{(1)} \quad \cdots
\end{aligned}
$$

where $f_{\mathrm{C}_{2}^{2-}}$ is the activity coefficient of $\mathrm{C}_{2}^{2-}$ ion.

From Eq. (3), $\log \left(\operatorname{mass} \% \mathrm{C}_{2}^{2-}\right)$ and $\log p_{\mathrm{O}_{2}}$ are expected to have a linear relationship with a slope of $-1 / 2$, under conditions of a fixed composition and temperature. The solubility of carbon in the $\mathrm{CaO}_{\text {satd }}-\mathrm{B}_{2} \mathrm{O}_{3}$ system $(78.0 \mathrm{~mol} \%$ $\mathrm{CaO})$ at $1773 \mathrm{~K}$ is shown as a function of $\log p_{\mathrm{O}_{2}}$, with the results of previous studies, in Fig. 1. Although the slope of the line, -0.37 is slightly lower than the expected value of -0.50 , it is close to the previous results. ${ }^{8-10)}$

The solubility of carbon in the $\mathrm{MO}-\mathrm{B}_{2} \mathrm{O}_{3}$ slags $(\mathrm{MO}=$ $\mathrm{CaO}, \mathrm{BaO}$, and $\left.\mathrm{Na}_{2} \mathrm{O}\right)$ under $p_{\mathrm{CO}}=1$ atm shows a minimum value (Fig. 2). The presence of the minimum solubility indicates that there would be a possibility for the dissolution of carbon by two types of mechanisms on either side of the minimum point. Hereafter, the slag composition will be divided into the acidic and the basic regions, based on carbon solubility. If Eq. (1) is valid over the entire composition range, $f_{\mathrm{C}_{2}^{2-}}$ must increase much faster than $a_{\mathrm{O}^{2-}}$ with increasing content of basic oxides, which seems unlikely. ${ }^{13,14)}$

The dissolution mechanism of carbon can be examined more quantitatively by considering the relationship between the solubility of carbon and the activity of basic oxides. In Eq. (3), $\log \left(\operatorname{mass} \% \mathrm{C}_{2}^{2-}\right)$ and $\log a_{\mathrm{O}^{2-}}$ are expected to have a linear relationship with a slope of unity at a fixed temperature and oxygen partial pressure, assuming that $f_{\mathrm{C}^{2-}}$ would not be affected by the slag composition. The solubility of carbon is shown as a function of the activity of basic oxides in Fig. 3, assuming that $a_{\mathrm{O}^{2-}}$ is directly proportional to $a_{\mathrm{MO}}$. The activity of $\mathrm{CaO},{ }^{\mathrm{O}^{2-}}{ }^{21)} \mathrm{BaO},{ }^{14,22}$ and $\mathrm{Na}_{2} \mathrm{O}^{23)}$ in the $\mathrm{B}_{2} \mathrm{O}_{3}$-bearing slags are available in the literature.

In the basic region of the $\mathrm{BaO}-\mathrm{B}_{2} \mathrm{O}_{3}$ and $\mathrm{Na} \mathrm{O}_{2} \mathrm{O}-\mathrm{B}_{2} \mathrm{O}_{3}$ slags, $\log (\operatorname{mass} \% \mathrm{C})$ and $\log a_{\mathrm{MO}}$ have a linear relation with the slope close to unity, although that in the $\mathrm{CaO}-\mathrm{B}_{2} \mathrm{O}_{3}$ slag is slightly lower than the expected value of unity. Based on these results, it is confirmed that the dissolution of

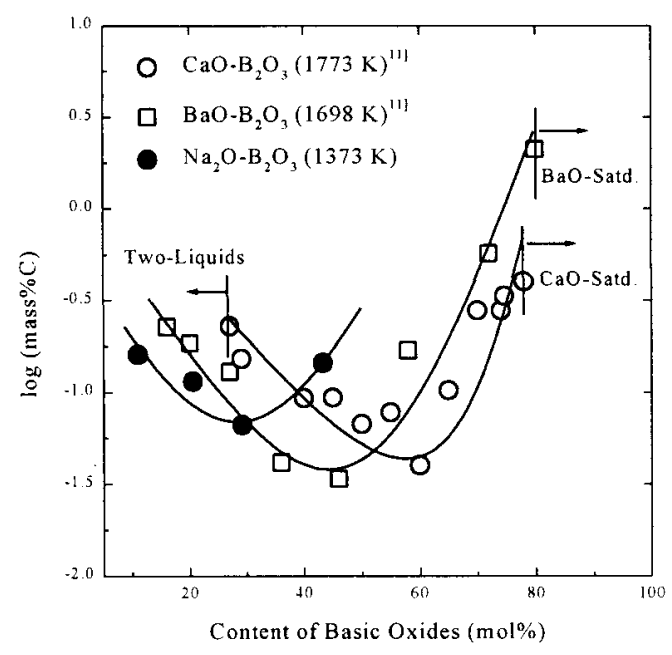

Fig. 2. Solubility of carbon in the $\mathrm{B}_{2} \mathrm{O}_{3}$-bearing slags as a function of the content of basic oxides in the molar basis.

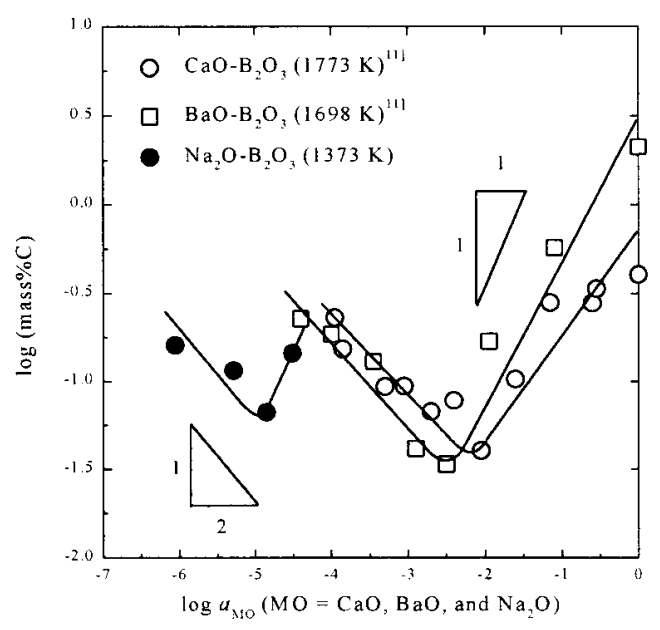

Fig. 3. Relationship between carbon solubility and the activity of basic oxides in the $\mathrm{B}_{2} \mathrm{O}_{3}$-bearing slags.

carbon into the basic slags can be described by Eq. (1).

However, in the acidic region of slags, it was difficult to explain the dissolution mechanism of carbon by Eq. (1). Hence, it was expected that there would be another reaction for carbon dissolution into the acidic slags.

\subsection{Dissolution Mechanism of Carbon in Acidic Slags}

The dependence of carbon solubility on oxygen partial pressure was measured at $1773 \mathrm{~K}$ in the 55.4 (mol\%) CaO$\mathrm{B}_{2} \mathrm{O}_{3}$ system. In Fig. 4, $\log ($ mass $\% \mathrm{C})$ linearly decreases with increasing $\log p_{\mathrm{O}_{2}}$ with a slope close to $-3 / 4$, which is higher than $-1 / 2$. Therefore, the dependence carbon solubility on oxygen partial pressure in the acidic region would be larger than that in the basic slags.

As shown in Fig. 3, the solubility of carbon in the acidic $\mathrm{B}_{2} \mathrm{O}_{3}$-bearing slags decreases by increasing the activity of basic oxides. The slopes of the lines for the $\mathrm{CaO}-, \mathrm{BaO}-$, and the $\mathrm{Na}_{2} \mathrm{O}-\mathrm{B}_{2} \mathrm{O}_{3}$ slags are $-0.41,-0.47$, and -0.52 , respectively, which are close to -0.5 . Consequently, the basicity term, $\mathrm{O}^{2-}$ should be placed on the right-hand side 


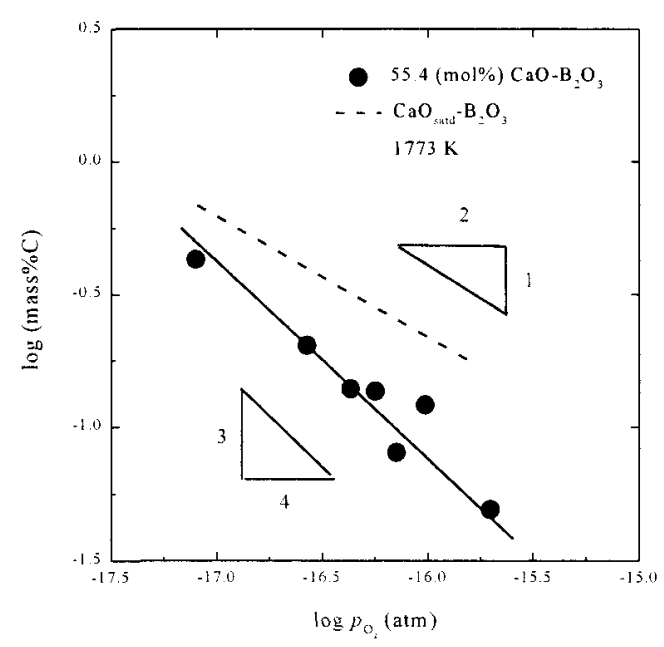

Fig. 4. Dependence of carbon solubility on oxygen partial pressure in the $\mathrm{CaO}-\mathrm{B}_{2} \mathrm{O}_{3}$ slags at $1773 \mathrm{~K}$.

in the dissolution reaction.

It has been known that there are three kinds of oxygen ions such as free $\left(\mathrm{O}^{2-}\right)$, non-bridging $\left(\mathrm{O}^{-}\right)$, and bridging oxygen ion $\left(\mathrm{O}^{0}\right)$ in molten slags. Generally, $\mathrm{O}^{2-}$ and $\mathrm{O}^{-}$ions would participate in the reaction more dominantly rather than $\mathrm{O}^{0}$ from the viewpoint of activation energy. ${ }^{13)}$ Therefore, carbon dissolution into the slags may be described by Eq. (4) based on the experimental results and the interactions between oxygen ions and carbon.

$$
\begin{aligned}
& \mathrm{C}(\mathrm{s})+2 \mathrm{O}^{-}(\text {slag })=\mathrm{C}^{-}(\text {slag })+3 / 4 \mathrm{O}_{2}(\mathrm{~g}) \\
& +1 / 2 \mathrm{O}^{2-} \text { (slag) } \\
& K_{(4)}=\frac{a_{\mathrm{C}^{-}} \cdot p_{\mathrm{O}_{2}}^{3 / 4} \cdot a_{\mathrm{O}^{2-}}^{1 / 2}}{a_{\mathrm{C}} \cdot a_{\mathrm{O}^{-}}^{2}} \\
& \log \left(\text { mass } \% \mathrm{C}^{-}\right)=-3 / 4 \log p_{\mathrm{O}_{2}}-1 / 2 \log a_{\mathrm{O}^{2-}} \\
& -\log f_{\mathrm{C}^{-}}+\log K_{(4)}+2 \log a_{\mathrm{O}^{-}}
\end{aligned}
$$

The carbide ion dissolved following Eq. (1), in the basic slags, may be referred to as "free carbide" and that following Eq. (4), in the acidic slags, as "incorporated carbide." From Eq. (6), $\log \left(\operatorname{mass} \% \mathrm{C}^{-}\right)$and $\log a_{\mathrm{O}^{2-}}$ are expected to have a linear relationship with a slope of $-1 / 2$ at a fixed oxygen partial pressure and temperature. In Fig. 3, the slopes of the lines in the acidic $\mathrm{B}_{2} \mathrm{O}_{3}$-bearing slags are close to $-1 / 2$; thus $f_{\mathrm{C}^{-}}$in Eq. (6) would be constant with the acidic slag composition. This is qualitatively confirmed from the estimated results that the activity coefficient of $\mathrm{BC}_{0.25}$ is independent of composition in each slag system, assuming that $\mathrm{BC}_{0.25}$ is the reference state of incorporated carbide. However, because the relationship between $a_{\mathrm{O}^{-}}$ and slag composition is not manifested, a more detailed investigation is required.

Considering the composition of $\mathrm{MO} \bullet 2 \mathrm{~B}_{2} \mathrm{O}_{3}(\mathrm{MO}=\mathrm{CaO}$, $\mathrm{BaO}$, and $\mathrm{Na}_{2} \mathrm{O}$ ), for example, exhibits the incorporation of carbon, the structure of molten slags could be represented by the ' $\mathrm{B}_{4} \mathrm{O}_{7}^{2-}$ ' diborate as a typical polymeric group, although so many polymeric groups would exist in the melt. ${ }^{15,21,24)}$ Hence, the reaction for the incorporation of carbon can be expressed by Eq. (7), based on the fact that

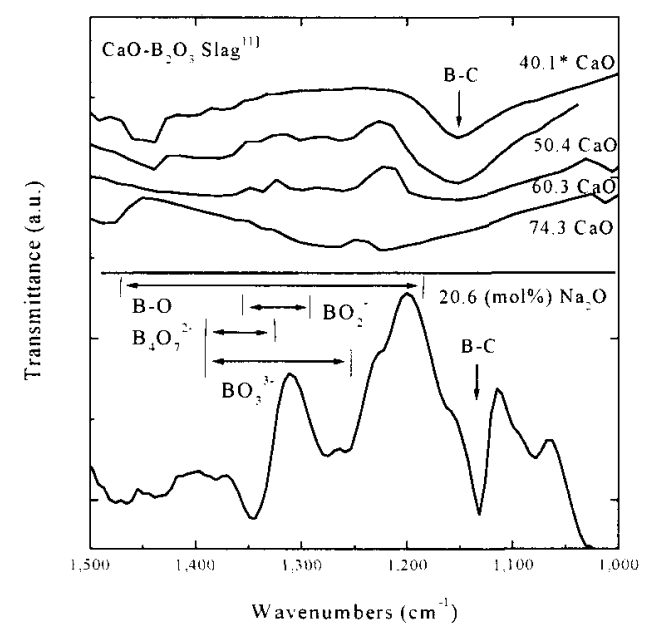

Fig. 5. IR transmittance of the $\mathrm{CaO}-\mathrm{B}_{2} \mathrm{O}_{3}$ and $20.6(\mathrm{~mol} \%) \mathrm{Na}_{2} \mathrm{O}-$ $\mathrm{B}_{2} \mathrm{O}_{3}$ slags as a function of wave numbers $\left(^{*}: \mathrm{mol} \%\right)$.

$\mathrm{B}_{2} \mathrm{O}_{3}$ is a network former in these slags:

$$
\begin{aligned}
& \begin{array}{cccc}
-\mathrm{O} & \mathrm{O}- & -\mathrm{O} & \mathrm{O}- \\
\mathrm{I} & \mathrm{I} & \mid \\
\mathrm{B}-\mathrm{O}-\mathrm{B} & \mathrm{B}-\mathrm{O}-\mathrm{B} \\
\mathrm{O} & \mathrm{O}^{-} & \mathrm{C}= & \mid \\
\mathrm{O} & \mathrm{O} & \mathrm{O} \\
\mathrm{B}-\mathrm{O}-\mathrm{B}-\mathrm{O}^{-} & \mathrm{B}=\mathrm{C}^{-}-\mathrm{B}-
\end{array} \\
& +3 / 4 \mathrm{O}_{2}+1 / 2 \mathrm{O}^{2-}
\end{aligned}
$$

From Eq. (7), it is suggested that the ' $B-O-B$ ' bonds would be replaced by the ' $\mathrm{B}=\mathrm{C}^{-}-\mathrm{B}$ ' bonds by introducing a carbon into the borate network. However, Eq. (7) is not an overall reaction for carbon incorporation, because the slag melt could be constituted by many other polymeric groups.

The incorporation of carbide into the borate network could be confirmed qualitatively by the Fourier transform infrared (FT-IR) measurements, as in the case of nitrogen, where the Si-N bond was found in the silicate melts. ${ }^{13,14,25)}$ In Fig. 5, the IR transmittance of the $\mathrm{CaO}-\mathrm{B}_{2} \mathrm{O}_{3}$ and $\mathrm{Na}_{2} \mathrm{O}-$ $\mathrm{B}_{2} \mathrm{O}_{3}$ slags is shown as a function of wave numbers in different compositions for comparison. The main peak for the $\mathrm{B}-\mathrm{O}$ stretching vibration (1470 to $1180 \mathrm{~cm}^{-1}$ ) is shifted to higher wave numbers with increasing $\mathrm{B}_{2} \mathrm{O}_{3}$ content. ${ }^{26)}$ Also, the peaks indicating the simple anionic group, such as $\mathrm{B}_{4} \mathrm{O}_{7}^{2-}$ (1380 to $\left.1330 \mathrm{~cm}^{-1}\right), \mathrm{BO}_{3}^{3-}$ (1380 to $1260 \mathrm{~cm}^{-1}$ ), and $\mathrm{BO}_{2}^{-}\left(1350\right.$ to $\left.1300 \mathrm{~cm}^{-1}\right)$ are appeared by increasing the content of $\mathrm{CaO}$, which modifies the borate structure. ${ }^{26}$ In addition, these anionic groups are appeared in the 20.6 (mol\%) $\mathrm{Na}_{2} \mathrm{O}-\mathrm{B}_{2} \mathrm{O}_{3}$ system, while occur in the composition higher than $50.4(\mathrm{~mol} \%) \mathrm{CaO}$ in the $\mathrm{CaO}-\mathrm{B}_{2} \mathrm{O}_{3}$ slag.

The IR region indicating the $\mathrm{B}-\mathrm{C}$ bond is known to be about 1255 to $1145 \mathrm{~cm}^{-1}$ in the literature. ${ }^{26)}$ In the acidic $\mathrm{Na}_{2} \mathrm{O}-\mathrm{B}_{2} \mathrm{O}_{3}$ system, the peak was found to be about 1140 $\mathrm{cm}^{-1}$, close to the results of the $\mathrm{CaO}-\mathrm{B}_{2} \mathrm{O}_{3}$ slags. ${ }^{11)}$ Based on these experimental results, it is suggested that carbon would dissolve into the acidic slags as incorporated carbide, as mentioned in Eq. (4), while as free carbide in the basic slags. 


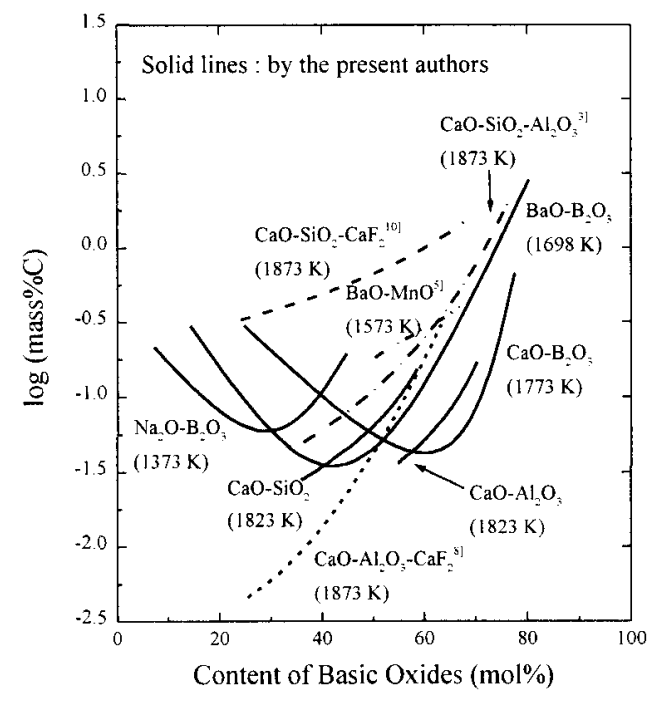

Fig. 6. Comparison of the dependence of carbon solubility on slag composition in various slags.

However, this is not conclusive proof of the incorporation of carbon into the borate network and a more detailed investigation is required to determine the coordination state of carbon in slags.

Fig. 6 exhibits the solubility of carbon in various slags as a function of the content of basic oxides. The effect of the slag components on carbon solubility can be discussed as follows.

In the $\mathrm{B}_{2} \mathrm{O}_{3}$-bearing slags, the minimum solubility of carbon is observed at about $60(\mathrm{~mol} \%) \mathrm{CaO}, 45(\mathrm{~mol} \%)$ $\mathrm{BaO}$, and $30(\mathrm{~mol} \%) \mathrm{Na}_{2} \mathrm{O}$, respectively. As in the case of silver solubility in the $\mathrm{B}_{2} \mathrm{O}_{3}$-bearing slags, the shifts of the composition for the minimum carbon solubility to the acidic one indicate that $\mathrm{Na}_{2} \mathrm{O}$ is more basic than $\mathrm{BaO}$, followed by $\mathrm{CaO}$, qualitatively. ${ }^{15-17)}$

In the $\mathrm{CaO}-\mathrm{RO}\left(\mathrm{RO}=\mathrm{B}_{2} \mathrm{O}_{3}, \mathrm{SiO}_{2}\right.$, and $\left.\mathrm{Al}_{2} \mathrm{O}_{3}\right)$ slags, the solubility of carbon decreases in the order of $\mathrm{CaO}-\mathrm{SiO}_{2}$, $\mathrm{CaO}-\mathrm{Al}_{2} \mathrm{O}_{3}$, and the basic $\mathrm{CaO}-\mathrm{B}_{2} \mathrm{O}_{3}$ slags at the same content of $\mathrm{CaO}$. This mainly due to the higher stability of carbide ion in the $\mathrm{CaO}-\mathrm{SiO}_{2}$ slag than those in other slags. ${ }^{8)}$

In addition, fluoride has been known to affect the thermodynamic behaviors of carbon and nitrogen in molten slags. ${ }^{8},{ }^{10},{ }^{12)}$ In the $\mathrm{CaO}-\mathrm{SiO}_{2}-\mathrm{CaF}_{2}$ and $\mathrm{CaO}-\mathrm{Al}_{2} \mathrm{O}_{3}-\mathrm{CaF}_{2}$ slags, the carbon solubility is higher than those in the $\mathrm{CaO}$ $\mathrm{SiO}_{2}$ and $\mathrm{CaO}-\mathrm{Al}_{2} \mathrm{O}_{3}$ slags, respectively. This may result from the effect of $\mathrm{F}^{-}$ion on the depolymerization reaction of slag structure instead of $\mathrm{O}^{2-}$ ion, in some proportion; hence the more $\mathrm{O}^{2-}$ ions could be reacted with carbon by Eq. (1). Also, effect of $\mathrm{CaF}_{2}$ on carbon solubility is more significant in the silicate than that in the aluminate melt.

\subsection{Relationship between Carbide Capacity and} Nitride Capacity

The free and incorporated carbide capacities can be defined by the following equations from Eqs. (2) and (5), respectively:

$$
C_{\mathrm{C}_{2}^{2-}}=\frac{K_{(1)} \cdot a_{\mathrm{O}^{2-}}}{f_{\mathrm{C}_{2}^{2-}}}=\left(\text { mass } \% \mathrm{C}_{2}^{2-}\right) \cdot p_{\mathrm{O}_{2}}^{1 / 2}
$$

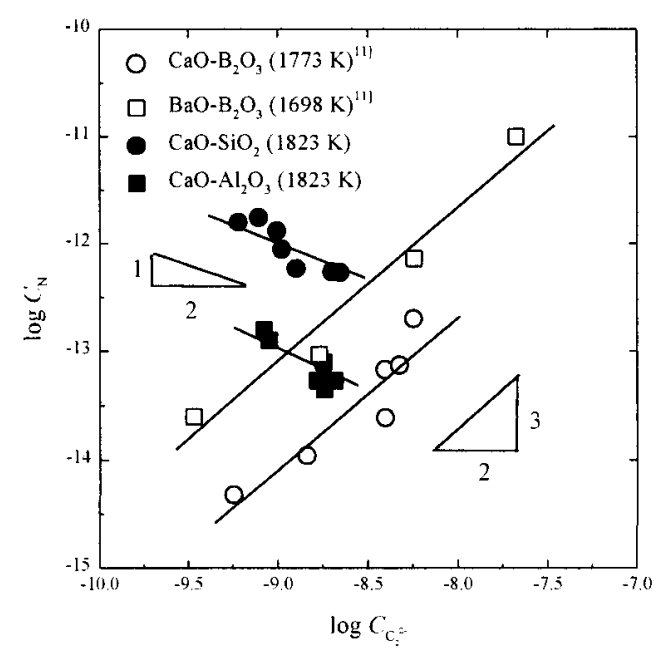

Fig. 7. Relationship between nitride and free carbide capacities in the $\mathrm{CaO}-\mathrm{SiO}_{2}, \mathrm{CaO}-\mathrm{Al}_{2} \mathrm{O}_{3}$, and the basic region of the $\mathrm{B}_{2} \mathrm{O}_{3}$ bearing slags.

$$
C_{\mathrm{C}^{-}}=\frac{K_{(4)} \cdot a_{\mathrm{O}^{-}}^{2}}{f_{\mathrm{C}^{-}} \cdot a_{\mathrm{O}^{2-}}^{1 / 2}}=\left(\text { mass } \% \mathrm{C}^{-}\right) \cdot p_{\mathrm{O}_{2}}^{3 / 4}
$$

where $p_{i}, K_{(\mathrm{n})}, a_{i}$, and $f_{i}$ are the partial pressure of $i$, the equilibrium constant of reaction (n), the activity, and the activity coefficient of $i$, respectively.

Combining these carbide capacities with the nitride capacities given in the literature, ${ }^{8}{ }^{12-14)}$ the relationship between them in the basic and acidic slags is derived, respectively, as follows:

$$
\begin{aligned}
& \log C_{\mathrm{N}^{3-}}=3 / 2 \log C_{\mathrm{C}_{2}^{2-}}+\log \frac{f_{\mathrm{C}_{2}^{2-}}^{3 / 2}}{f_{\mathrm{N}^{3-}}}+\log K^{\prime} . \\
& \log C_{\mathrm{N}^{-}}=\log C_{\mathrm{C}^{-}}+\log \frac{f_{\mathrm{C}^{-}}}{f_{\mathrm{N}^{-}}}+\log K^{\prime \prime} \ldots \ldots \ldots .
\end{aligned}
$$

Thus, nitride and carbide capacities are expected to have a linear relationship with the slope of $3 / 2$ and 1 , respectively, if the other terms are constant. In Fig 7, $\log C_{\mathrm{N}^{3-}}$ from the literature is plotted as a function of $\log C_{\mathrm{C}_{2}^{2-}}$ in the basic $\mathrm{CaO}-\mathrm{B}_{2} \mathrm{O}_{3}$ and $\mathrm{BaO}-\mathrm{B}_{2} \mathrm{O}_{3}$ slags. ${ }^{14)}$ The slope of the former is 1.4 and that for the latter is 1.5 , which are relatively close to the expected value of $3 / 2$. Hence, the $f_{\mathrm{C}_{2}^{2-}}^{3 / 2} / f_{\mathrm{N}^{3-}}$ ratio in Eq. (10) may be nearly constant in the basic region of each slag system.

The slope of the lines is negative in the $\mathrm{CaO}-\mathrm{SiO}_{2}$ and $\mathrm{CaO}-\mathrm{Al}_{2} \mathrm{O}_{3}$ slags. The solubility of nitrogen in these slags decreased with increasing $\mathrm{CaO}$ content, ${ }^{27,28)}$ indicating that nitrogen would dissolve as incorporated nitride; thus in the $\mathrm{CaO}-\mathrm{SiO}_{2}$ and $\mathrm{CaO}-\mathrm{Al}_{2} \mathrm{O}_{3}$ slags, the following equation is deduced.

$$
\begin{aligned}
\log C_{\mathrm{N}^{-}}=- & 1 / 2 \log C_{\mathrm{C}_{2}^{2-}}+\log \frac{1}{f_{\mathrm{N}^{-}} \cdot f_{\mathrm{C}_{2}^{2-}}^{1 / 2}} \\
& +\log K^{\prime \prime \prime}+2 \log a_{\mathrm{O}^{-}} \ldots \ldots \ldots \ldots \ldots
\end{aligned}
$$

Thus, $\log C_{\mathrm{N}^{-}}$is expected to have a linear relationship with $\log C_{\mathrm{C}_{2}^{2-}}$ if the other terms are constant, and the theoretical slope will be $-1 / 2$. The slope of the line in the $\mathrm{CaO}-\mathrm{SiO}_{2}$ slag is -0.58 and that for the $\mathrm{CaO}-\mathrm{Al}_{2} \mathrm{O}_{3}$ slag is -0.66 , which is relatively close to the expected value of $-1 / 2$. 


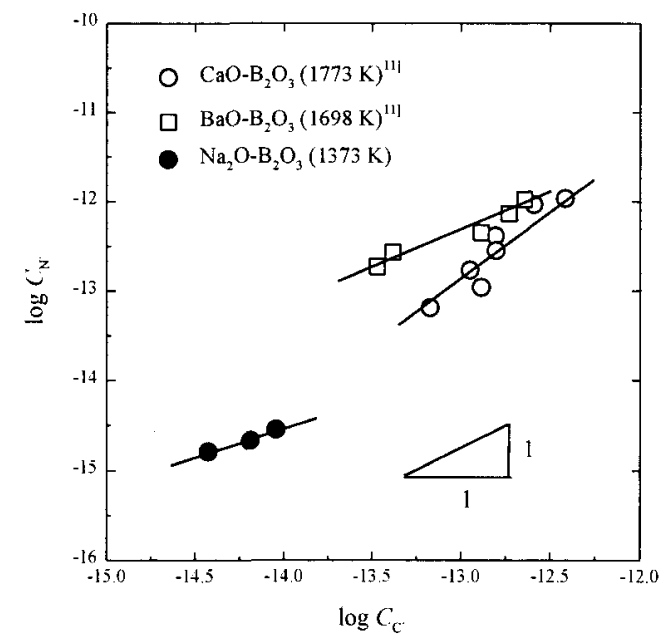

Fig. 8. Relationship between incorporated nitride and carbide capacities in the acidic region of the $\mathrm{B}_{2} \mathrm{O}_{3}$-bearing slags.

Hence, the terms of $f_{\mathrm{N}^{-}} \cdot f_{\mathrm{C}_{2-}^{2-}}^{1 / 2}$ and $a_{\mathrm{O}^{-}}$may be constant. Based on these results, the thermodynamic behaviors of nitrogen and carbon in the $\mathrm{B}_{2} \mathrm{O}_{3}$-bearing slags are similar, while different behaviors are shown in the $\mathrm{CaO}$ $\mathrm{SiO}_{2}$ and $\mathrm{CaO}-\mathrm{Al}_{2} \mathrm{O}_{3}$ slags.

Fig. 8 exhibits the relationship between $\log C_{\mathrm{N}^{-}}$and $\log C_{\mathrm{C}^{-}}$in the acidic $\mathrm{B}_{2} \mathrm{O}_{3}$-bearing slags. ${ }^{14,29)}$ The slope of the $\mathrm{CaO}-\mathrm{B}_{2} \mathrm{O}_{3}$ system is 1.4 , slightly higher than the expected value of unity, and those of the $\mathrm{BaO}-$ and $\mathrm{Na}_{2} \mathrm{O}$ $\mathrm{B}_{2} \mathrm{O}_{3}$ systems are 0.78 and 0.64 , lower than the expected value. From these differences, it can be suggested that $f_{\mathrm{C}^{-}}$ would be larger than $f_{\mathrm{N}^{-}}$in the $\mathrm{CaO}-\mathrm{B}_{2} \mathrm{O}_{3}$ system, and vice versa in the $\mathrm{BaO}$ - and $\mathrm{Na}_{2} \mathrm{O}-\mathrm{B}_{2} \mathrm{O}_{3}$ systems, in Eq. (11). As seen in Figs. 7 and 8, the dissolution of carbon and nitrogen into the $\mathrm{B}_{2} \mathrm{O}_{3}$-bearing slags shows a similar behavior.

\section{Conclusions}

The solubility of carbon in the $\mathrm{MO}-\mathrm{B}_{2} \mathrm{O}_{3}(\mathrm{MO}=\mathrm{CaO}$, $\mathrm{BaO}$, and $\left.\mathrm{Na}_{2} \mathrm{O}\right)$ and $\mathrm{CaO}-\mathrm{RO}\left(\mathrm{RO}=\mathrm{SiO}_{2}\right.$ and $\left.\mathrm{Al}_{2} \mathrm{O}_{3}\right)$ slags was measured at high temperatures to understand the thermodynamic behavior of carbon in molten slags. The results of this study can be summarized as follows:

(1) The dissolution of carbon into the basic region of the $\mathrm{B}_{2} \mathrm{O}_{3}$-bearing slags and into the $\mathrm{CaO}-\mathrm{RO}$ slags is confirmed by the following reaction:

$$
2 \mathrm{C}(\mathrm{s})+\mathrm{O}^{2-}(\mathrm{slag})=\mathrm{C}_{2}^{2-}(\mathrm{slag})+1 / 2 \mathrm{O}_{2}(\mathrm{~g})
$$

(2) The dissolution mechanism of carbon into the acidic region of the $\mathrm{B}_{2} \mathrm{O}_{3}$-bearing slags can be suggested by the following reaction from the effect of basicity and oxygen partial pressure on the solubility of carbon:

$$
\begin{aligned}
\mathrm{C}(\mathrm{s})+2 \mathrm{O}^{-}(\text {slag })= & \mathrm{C}^{-}(\text {slag })+3 / 4 \mathrm{O}_{2}(\mathrm{~g}) \\
& +1 / 2 \mathrm{O}^{2-}(\text { slag })
\end{aligned}
$$

(3) The infrared spectra measurements indicate that the $\mathrm{B}-\mathrm{C}$ bond is about 1150 and $1140 \mathrm{~cm}^{-1}$ in the acidic $\mathrm{CaO}$ $\mathrm{B}_{2} \mathrm{O}_{3}$ and $\mathrm{Na}_{2} \mathrm{O}-\mathrm{B}_{2} \mathrm{O}_{3}$ slags; hence, the incorporation of carbon into the borate network is confirmed qualitatively.

(4) The dissolution of carbon and nitrogen into the slags shows a similar behavior in the $\mathrm{B}_{2} \mathrm{O}_{3}$-bearing slags, while different behavior is shown in the $\mathrm{CaO}-\mathrm{SiO}_{2}$ and $\mathrm{CaO}-$ $\mathrm{Al}_{2} \mathrm{O}_{3}$ slags, based on the relationship between carbide capacity and nitride capacity.

\section{Acknowledgment}

The authors express their appreciation to the Korea Science and Engineering Foundation (Grant No. 97-030008-01-3) for financial support of this research work.

\section{REFERRENCES}

1) Z. Morita and T. Emi: An Introduction to Iron and Steel Processing, Kawasaki Steel 21 st Century Foundation, Tokyo, 1997.

2) J. H. Swisher: Trans. TMS-AIME, 242 (1968), 2033.

3) A. G. Ponomarenko and Y. E. Kozlov: Russ. Metall., 5 (1974), 61.

4) R. A. Berryman and I. D. Sommerville: Metall. Trans. B, 23B (1992), 223.

5) Y. Watanabe, K. Kitamura, I. P. Rachev, F. Tsukihashi, and N. Sano: Metall. Trans. B, 24B (1993), 339.

6) M. Kuwata and H. Suito: Metall. Mater. Trans. B, 27B (1996), 57.

7) K. R. Lee and H. Suito: Steel Res., 67 (1996), 87

8) H. S. Song: Ph.D. Thesis, Pohang University, Korea, 1996.

9) M. Mori, K. Morita, and N. Sano: Metall. Mater. Trans. B, 28B (1997), 1257.

10) H. S. Song, C. H. Rhee, and D. J. Min: Steel Res., 70 (1999), 105.

11) J. H. Park and D. J. Min: Metall. Mater. Trans. B, 30B (1999), 1045.

12) I. Sohn, D. J. Min, and J, H, Park: Steel Res., 70 (1999), 215.

13) K. Ito and R. J. Fruehan: Metall. Trans B, 19B (1988), 419.

14) D. J. Min and R. J. Fruehan: Metall. Trans. B, 21 B (1990), 1025.

15) J. H. Park and D. J. Min: J. Kor. Inst. Met. Mater., 37 (1999), 1124.

16) J. H. Park and D. J. Min: Metall. Mater. Trans. B, 30B (1999), 689.

17) J. H. Park and D. J. Min: Mater. Trans., JIM, 41, in print.

18) M. Kowalski, P. J. Spencer, and D. Neuschutz: Slag Atlas, 2nd. Ed., Verlag Stahleisen GmbH, Dusseldorf, (1995), 39-98.

19) E. T. Turkdogan: Physical Chemistry of High Temperature Technology, Academic Press, New York, NY, (1980), 1-24.

20) H. Ono, A. Kobayashi, F. Tsukihashi, and N. Sano: Metall. Trans. B, 23B (1992), 313.

21) F. D. Richardson: Physical Chemistry of Melts in Metallurgy, Academic Press, London, (1974), vol. 1, 87-140.

22) D. J. Min: J. Kor. Inst. Met. Mater, 33 (1995), 1212.

23) J. H. Park and D. J. Min: J. Kor. Inst. Met. Mater, 38, in print.

24) F. Muller and S. Demirok: Glastech. Ber., 62 (1989), 142.

25) E. Martinez and N. Sano: Metall. Trans. B, 21 B (1990), 97.

26) G. Socrates: Infrared Characteristic Group Frequencies, 2nd. Ed., John Wiley \& Sons, Chichester, (1994), 195-243.

27) K. Tomioka and H. Suito: ISIJ Int., 31 (1991), 1316.

28) K. Tomioka and H. Suito: Steel Res., 63 (1992), 1.

29) S. J. Kong: M.S. Thesis, Pohang University, KOREA, 1999. 